\title{
Adoption of Children by Homosexual Couples: The Social Representations
}

\author{
José Victor De Oliveira Santos ${ }^{1, *}$ \\ Orcid.org/0000-0002-6661-2873 \\ Ludgleydson Fernandes de Araújo ${ }^{1}$ \\ Orcid.org/0000-0003-4486-7565 \\ Fauston Negreiros ${ }^{1}$ \\ Orcid.org/0000-0003-1116-6391 \\ Elder Cerqueira-Santos ${ }^{2}$ \\ Orcid.org/0000-0003-2046-8463
}

${ }^{1}$ Universidade Federal do Piauí, Parnaiba, PI, Brasil ${ }^{2}$ Universidade Federal do Sergipe, Aracaju, SE, Brasil

\begin{abstract}
This study aimed to identify the social representations of adoption by homosexual couples in the Brazilian reality. Participants where 589 adults of both genders, aged between 18 and 69 years $(M=27.43, S D=9.0)$ from diverse backgrounds. Structured interviews and sociodemographic questionnaires were used and were analyzed using the IRaMuTeQ software, which organized the social representations into classes of lexical proximity. Results showed, a Descending Hierarchical Classification, with two classes in the corpus of same-sex parent adoption and five classes in the corpus about childhood development. These mainly highlighted positive social representations, always seeking the best for the adoptee as the justification, however, unfavorable positions found reflected the fear that the child would not be able to cope with the family model. In this sense, it is believed that the social representations about adoption by homosexual couples documented in this study indicate concepts that could support social interventions that increase the civil rights of homosexual parents.
\end{abstract}

Keywords: Adoption, same-sex parenting, social representations, Brazilian adults.

\section{Adoção de Crianças por Casais Homossexuais: As Representações Sociais}

\section{Resumo}

A presente pesquisa objetivou identificar as representações sociais da adoção por casais homoafetivos na realidade brasileira. Participaram 589 adultos, de ambos os sexos, com idades entre 18 e 69 anos $(M=27,43, D P=9,0)$ de diferentes regiões do país. Utilizaram-se entrevistas estruturadas e question-

* Mailing address: Universidade Federal do Piauí, Departamento de Psicologia, Av. São Sebastião, 2819, Parnaíba, PI, Brazil 64202-020. E-mail: victorolintos@hotmail.com, ludgleydson@yahoo.com.br, faustonnegreiros@ufpi.edu.br and eldercerqueira@gmail.com Financiamento: Conselho Nacional de Desenvolvimento Científico e Tecnológico - CNPq. 
ários sociodemográficos que foram analisados pelo software Iramuteq, que por sua vez apreendeu as representações sociais em classes de proximidade lexical. Os resultados apontaram, na Classificação Hierárquica Descendente, duas classes no corpus sobre adoção homoparental e cinco classes no corpus acerca do desenvolvimento infantil. Em sua maioria os resultados apontaram representações sociais positivas, sempre visando o melhor para o adotando como justificativa, por outro lado posicionamentos desfavoráveis encontrados refletem o receio da criança não conseguir lidar com o modelo familiar. Nesse sentido, acredita-se que as representações sociais acerca da adoção por casais homoafetivos documentadas neste estudo apontam conceitos que possam subsidiar medidas sociais que tragam ainda mais direitos para pessoas homossexuais.

Palavras-chave: Adoção, homoparentalidade, representações sociais, adultos brasileiros.

\section{La Adopción de los Niños por Parejas Homosexuales: Las Representaciones Sociales}

\section{Resumen}

Esta investigación tuvo como objetivo identificar las representaciones sociales de la adopción por parejas homosexuales en la realidad brasileña. Participaron 589 adultos de ambos sexos, con edades entre 18 y 69 años $(M=27.43, D E=9.00)$ en diferentes regiones. Se utilizarón entrevistas estructuradas y cuestionarios sociodemográficos fueron analizados por el software Iramuteq, que se hizo con las representaciones sociales en las clases de proximidad léxicos. Los resultados mostraron, la clasificación jerárquica descendente, dos clases en el corpus de la adopción homoparental y cinco clases en el corpus sobre el desarrollo infantil, en su mayoría han demostrado las representaciones sociales positivas, buscando siempre la mejor para la adopción como justificación, sin embargo posiciones desfavorables encontradas reflejan el miedo del niño no puede manejar el modelo de familia. En este sentido, se cree que las representaciones sociales acerca de la adopción por parte de parejas homosexuales documentados en este studio indican conceptos que pueden apoyar medidas sociales todavía traen más derechos para las personas homosexuales.

Palabras clave: Adopción, homoparentalidad, representaciones sociales, adultos brasileños.

The family model presented as the standard (father, mother and children), which had its prime in the twentieth century, has been altering according to some social changes. With the increase of new family configurations the nuclear model will make room for other forms of family organization, in addition to the patriarchal style, with single parent and same-sex parent families (Bergman, Rubio, Green, \& Padròn, 2010; Murphy, 2013). The constitution and maintenance of the family depend on affective bonds and not necessarily on legal and/or religious marriage, with these bonds leaving aside the principles of reproduction and seeking other designs to achieve filiation, based on forms of companionship and affection (Delacruz \& Uziel, 2014).

The authors Dias and Reinheimer (2013) emphasize that with the advance of legal achieve- ments in terms of human rights, the concept of family is no longer associated with the celebration of marriage. Because of this, the recognition of same-sex parenting by the population proves that families formed by homosexual couples are close to having the rights that any other family model should possess. In this context, it is known that the number of people who declared themselves homosexuals is increasing and, as a consequence of this, the appearance of same-sex parent families is becoming more frequent. Brazil has about 60,000 gay couples, a significantly small amount given the national contingent that declares itself homosexual, this being 17 million people (Instituto Brasileiro de Geografia e Estatística [IBGE], 2011).

Since the 1990s, the struggle for gay rights has intensified, primarily seeking recognition of 
conjugality by same-sex couples, adoption opportunities and combating homophobia (Uziel, 2007). People should not merely wait for homosexual rights to be accepted legally, with it being necessary to consolidate these advances, since the consecration of such rights can be a convenient way to reduce manifestations of prejudice (Dias \& Reinheimer, 2013).

The National Council of Justice (CNJ), through Resolution No. 175 of May 14, 2013, established that authorities were forbidden to refuse same-sex couples the right to a marriage license, civil wedding ceremony or to replace a stable union arrangement with marriage. This resolution ensures rights previously possible only for heterosexual couples, namely, equality in rights and duties of the spouses, separation with division of property, right to alimony and inheritance, among others.

Same-sex parent adoption is understood as the mode of adoption in which the adoptive couple are homosexuals (Patterson, 2006) or just one individual who is homosexual. The denomination same-sex parenting was developed in 1996 in France, through the initiative of the Association of Gay and Lesbian Parents and Future Parents (Zambrano, 2006). However, even two decades after this term was first used, resistance to considering the legitimacy to homosexual couples and their children as family can still be visualized.

The Statute of Children and Adolescents (Law No. 8.069, 2014) states that for joint adoption, it is necessary for the adopters to be civilly married or in a stable union, proving the family stability, and for the adoption to be granted to show real benefits for the adoptee. No term mentions that adoption by same-sex parents is possible, however, none prohibit it either, therefore, the sexual orientation should not be a criterion for the exclusion or prioritization of adoption candidates. According to the analysis of Cerqueira-Santos and Santana (2015), there is no legal prohibition for the institution of adoption of children by homosexual couples in the country.

In this context, in March 2015, the Minister Carmen Lucia, of the Supreme Court, granted the right of adoption to a homosexual couple for the first time in Brazil (Foster, 2015 apud Fiuza, 2015). However, despite the achievement of these rights, which leads to greater visibility and positive situations given the theme, it would be an illusion to say that manifestations of prejudice are occurring to a lesser extent, in the country (Freires, 2015). This prejudice could be compared to that dedicated to the 1970 Divorce Act, which at the time was regarded with scorn and now has become something common, inducing the notion that society takes a certain amount of time to internalize some events (Uziel, 2007).

Regarding the forms of parenthood, Grossi (2003) states that the scientific literature highlights four forms of same-sex parent filiation: (a) Having children in heterosexual relationships prior to assuming homosexuality; (b) Adoption by one of the partners, being the legal representative of the child; (c) Procreation with a third individual outside the marital relationship through new reproductive technologies and, finally, (d) Co-parenthood among gay and lesbian people. It is noted that the CNJ (2015) already allows the inclusion of gay couples in the national registry of adoption, therefore this would be the fifth model of filiation, and an important achievement in the civil rights of homosexual families.

The challenge of finding an appropriate way to have a child becomes distressing, the inability to generate offspring requires psychic work, involving the decision to abandon the narcissistic principle of biological continuity and accept external agents for the conception of the child (Passos, 2005). This author also emphasizes that the difficulties of conception of a child often causes the abandonment of the desire to have a child.

In the case of the formation of a same-sex parent family and adoption, the requirements of the children and adopters, who are the social actors involved in this psychosocial process, should be considered (Almeida, 2008). Thus, it is important to highlight that the discourse of common sense - usually based on their religious beliefs - is the basis for forms of expressions of prejudice toward homosexual people, demonstrating ways of repudiation of the marriage and adoption, attitudes that can be understood through the social representations about ho- 
mosexuals (Pereira, Torres, Falcão, \& Pereira, 2013).

Despite the authorization of same-sex parent adoption, the non-recognition of the population reflects in prejudicial attitudes, possibly because the state does not provide this cause with the due legal support, that is, there is legislation, however, in the articulation of the practices, it is not properly executed (Cerqueira-Santos \& Santana, 2015; Silva \& Silveira, 2015). In this way, it is perceived that the happiness of a couple seeking to adopt and the opportunity to include a child in a family are left aside, in order to comply with the notions that were fixed in society, however, which need to be reconsidered. The inaccessibility of scientific information on the subject is something that leads to biased opinions on same-sex parenting, making the issue a social and educational challenge of awareness (Gato \& Fontaine, 2010).

In a systematic review of the literature, Cecílio, Scorsolini-Comin, and Santos (2013) highlighted that, in Brazil, in one decade (20002010) only ten studies on same-sex parent adoption were conducted and published in the main scientific databases of the country. Among them, three articles were empirical and seven theoretical. The authors highlighted three main trends in the studies on the subject: the concern with the consequences of the adoption for the children (negative and positive developmental aspects); alternatives in the pursuit of parenthood; and issues relating to the adoption itself (law, historical changes and others).

A previous study verified that the respondents believed that same-sex parent adoption is a more viable solution when compared to the possibility of children growing up in shelter institutions, being an excellent option given the lack of other alternatives (Silva \& Uziel, 2011). In this concept, therefore, there is a discourse of the lesser evil (Uziel, 2007; i.e., it is a lesser evil for the development of the child to occur in a samesex parent family, given the possibility of being raised in a shelter).

A survey conducted in Portugal, which sought to analyze the opinion of university students regarding same-sex parenting, showed that
$66 \%$ of the subjects were against equal rights in the exercise of parenthood (Xavier, Mendes, Martins, \& Fernandes, 2011). In another study performed with Brazilian university students from the perspective of social representations, it was found that $51 \%$ of the respondents were against adoption by homosexual couples, this result may be indicated by the representation that the fact would constitute inappropriate development and the child could follow the sexual orientation of the parents (Araújo, Oliveira, Sousa, \& Castanha, 2007). Thus, data in line with the investigations of the aforementioned authors were demonstrated among university students of Law and Social Work (Cerqueira-Santos \& Santana, 2015). Such discourses are based on negative stereotypes and attitudes regarding the theme, since there is no proven scientific evidence that same-sex parenting is harmful for the adoptee (Silva \& Uziel, 2011).

In a recent work, Freires (2015) talked about attitudes towards same-sex parenting, from five studies. In general the study sought to map the opinion of the participants regarding same-sex parent adoption. As a result, the discourse of acceptance was observed, provided there was a favorable environment for the development of the child. The implicit concern about the development of the child ends up generating prejudiced opinions because of concern about the influence of the social roles of gender. In this sense, scientific investigations are necessary, with the aim of verifying the knowledge developed and shared (the social representations) by social groups about adoption by homosexual couples.

From the perspective of Social Psychology, the Theory of Social Representations provides a broader view about the beliefs, concepts and explanations that people express through common sense (Moscovici, 2003). Thus, social representations are forms of knowledge popularly developed, anchored and shared, constructing concepts for the reality of a social group (Jodelet, 2001). They comprise a tool to analyze the beliefs of the reality, arising from the acquisition of new thoughts and questions within the science (Arruda, 2002). 
In the context of same-sex parent adoption, the social representations surround the set of opinions, attitudes and reactions to this phenomenon, which pervade the social and personal constructs of the subject. These factors are responsible for producing negative or positive responses and creating beliefs of prejudice and intolerance or acceptance (Araújo \& Oliveira, 2008).

Given the above, this study aimed to analyze how adults of several Brazilian regions represent the adoption by homosexual couples, with social representations as the theoretical framework, which involves social and cognitive aspects and makes it possible to interpret the socially developed concepts, with the intention of deepening and enriching discussions on the theme.

\section{Method}

\section{Type of Study}

This is an ex post facto study using crosssectional data.

\section{Participants}

The sample consisted of 589 adults, of both genders, aged between 18 and 69 years $(M=27.43, S D=9.0)$ from different regions of Brazil. Women made up the majority of the study sample $(60.3 \%)$ ). Of the participants, $71.1 \%$ were single, $19.7 \%$ married, and the rest of the sample was composed of those in a stable union $(6.3 \%)$, divorced or separated (2.8\%) and widowed $(0.1 \%)$. Regarding education, $50.5 \%$ of the participants were attending higher education, $23.9 \%$ were postgraduates and $15.9 \%$ had completed higher education, with $9.8 \%$ of the sample having high school and elementary education. With regard to sexual orientation, $84.2 \%$ of the participants were heterosexual and $11.6 \%$ homosexual or bisexual. Considering religion, $35.7 \%$ were Catholic, $24.5 \%$ believed in God, but followed no religion, $11.6 \%$ were non-practicing Catholics, $10.2 \%$ Evangelists, $6.0 \%$ Spiritualists and the others identified themselves as atheists, Jehovah's witnesses, Buddhists and practitioners of Candomblé or Umbanda. According to the political positions, $36.7 \%$ said they were left, $25.5 \%$ center-left, $14.8 \%$ center-right and $23.0 \%$ right.

\section{Instruments}

The instrument used initially was a sociodemographic questionnaire, in order to perform a characterization of the sample, consisting of questions relating to age, gender, marital status, religion or spirituality, sexual orientation and level of education. Next, two questions were asked, based on previous studies (Araújo \& Oliveira, 2008; Araújo et al., 2007; Freires, 2015). These questions addressed the social representations of adoption and childhood development in the same-sex parent context. The first, "What is your opinion regarding the adoption of children by homosexual couples?" The second, "What is your opinion regarding the childhood development of a child adopted by a homosexual couple?".

\section{Ethical Procedures}

This research project was approved by the Research Ethics Committee (CEP) of Federal University of Piaui. Data were collected using a Google Docs form (Online). The participants for the composition of the sample were contacted through social and email networks. In the data collection, it was made clear that participation was voluntary and anonymous, explaining the study objectives, obtaining the proper authorizations, as well as the fulfillment of the Terms of Consent in accordance with the provisions of Resolution 466/12 of the National Health Council (CNS), so that the participants could authorize their participation in the study and respond to the instruments. It should be noted that anonymity and confidentiality of the responses of the participants were guaranteed and that they could withdraw from the study at any time. The time necessary for participation was approximately 30 minutes.

\section{Data Analysis Procedure}

The IRaMuTeQ software - Interface de $R$ pour les Analyses Multidimensionnelles de Textes et de Questionnaires (Camargo \& Justo, 2013; Nascimento \& Menandro, 2006; Ratinaud, 2009) was used for the data analysis, which is compiled from the $\mathrm{R}$ software ( $\mathrm{R}$ Development Core Team, 2011). It was used for analyzing the 
two textual corpus attributed to the two questions answered by the participants in the sample. These corpus were structured in the OpenOffice Writer text editor and were composed of 600 Initial Context Units (ICUs). Descriptive analyzes were performed using the IBM SPSS Statistics 21 software.

In the analysis, the procedure of Descending Hierarchical Classification (DHC) was conducted, which is displayed in a tree format (i.e., a dendrogram). This indicates the lexical classes into which the discourse was divided, from the frequency and chi-squared $\left(X^{2}\right)$ values, with this model proposed by Reinert (1990).

\section{Results}

Regarding the question about the social representations of adoption by homosexual couples, which makes up corpus 1 , diverse positions were found, however, the majority were in favor of adoption. This was formed by 589 ICUs and 672 Elemental context units (ECUs), with a total equivalent to 13,753 occurrences, which may be words or distinct phrases. From the descending hierarchical classification (DHC) analysis, they were divided into two lexical classes, documenting only those in which the chi-square showed $X^{2}$ value $\geq 12.52$.

The two classes are registered in dendrogram 1, which could be termed the "assertive concept" and "partially supportive concept", corresponding respectively to classes 1 and 2 . The ECUs per class, the descriptive variable that represents the sample, the mean frequency of each word and the chi-squared values are indicated. Class 1, as can be seen in Figure 1, was represented by $79.15 \%$ of the ECUs. Regarding the descriptive variables, bisexual people and/or Spiritualists presented discourses that most coincided with that obtained in class 1 and the heterosexual people in class 2. It is emphasized that the use of descriptive variables shows the social representations of that profile that most coincided with the representational class type, however, this does not mean that it was formed only by the descriptive variables mentioned in the dendrogram. It was seen that class 1 represented the majority of the sample (i.e., it had more semantic relevance).

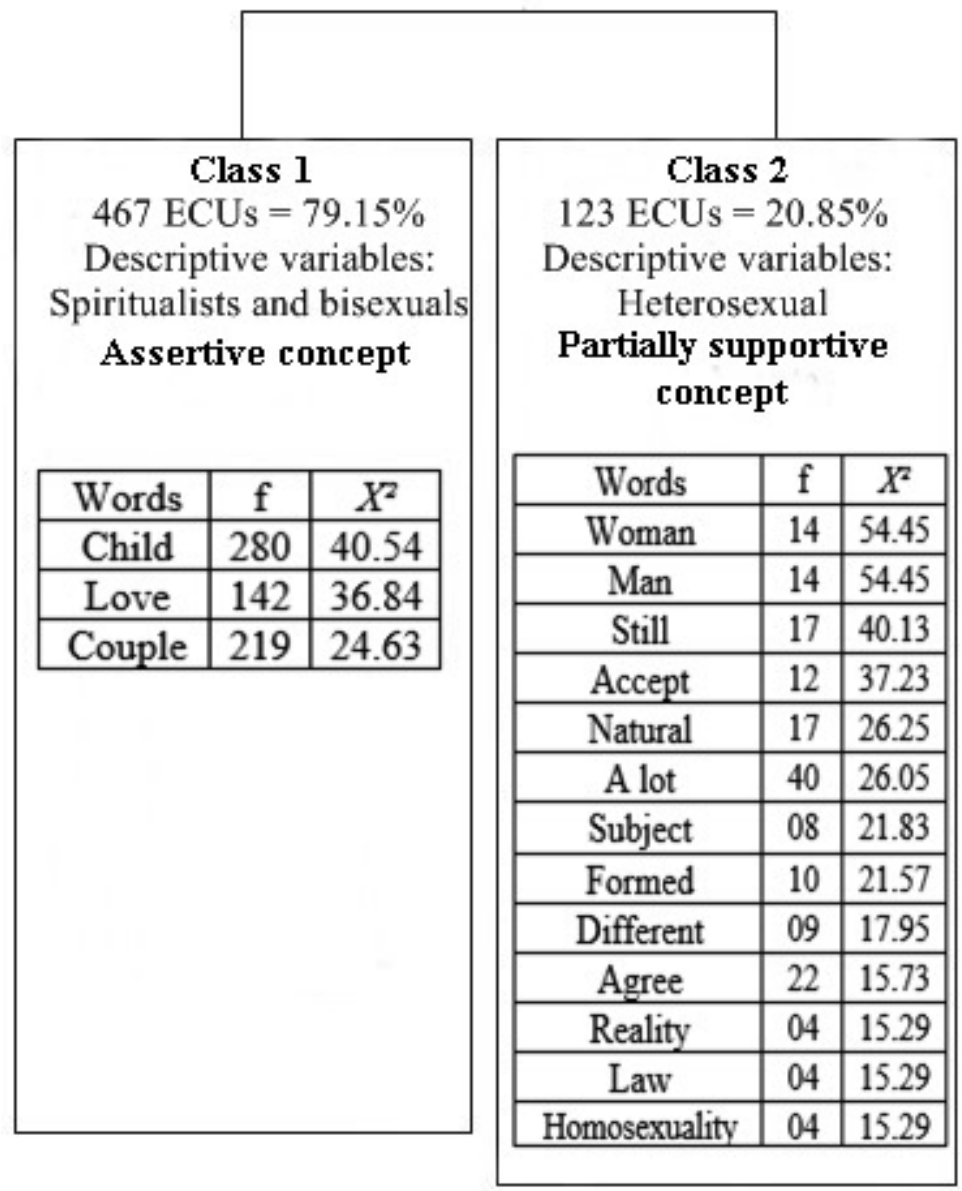

Figure 1. Dendrogram 1, distribution of the classes in the Social Representations of same-sex parent adoption. 
It should be noted that the social representations of same-sex parent adoption are associated with issues involving reciprocal love between the child and adoptive couple. As can be seen in Figure 1, assertiveness was found to be present, which can infer representations linked to the love that the couple will bestow upon the child, this being the most important factor for the development of the adoptee. These representations can be perceived in the discourse of some participants, such as participant 064,22 years of age, who believed in God but did not follow any religion, was heterosexual and an undergraduate student, and said "It is a normal thing, considering that, what matters is the love, care and education that will be given to the child".

The issue of care, love and the well-being of the child as the key factors for adoption becomes anchored in the same-sex parent context, with it being totally wrong to discern the ability of a couple to adopt from their sexuality, as can be evidenced in this statement: "I do not see any impediment, the adoption must serve the child, offering it a family that can provide love and care, and for that, the sexual orientation of the couple does not matter" (Participant 405, 21 years of age, incomplete higher education, woman, heterosexual, believed in God, but had no religion).

Class 2 was composed of 123 ECUs, equivalent to $20.85 \%$ of the total, with a wider range of words observed, constituting social representations based on concepts partially supportive of the adoption, in which they accept the adoption if there are dignified conditions for the development of adoptee, however, individuals with unfavorable positions are also found.

As demonstrated in Class 2 (see Figure 1) the words that most represent this class are women and men, these, which were used as a comparison in relation to homosexual couples, which in turn, justified that they were supportive of the adoption by considering it natural, although different, because there exist many concepts formed regarding the theme, which in turn, are filled with stigmas associated with the homosexual person.

This statement exemplifies one of the views that composed class 2: "Acceptable, children need a home. And a homosexual couple would devote themselves to their adopted children the same as a heterosexual couple" (Participant 034, 18 years of age, incomplete higher education, woman, heterosexual, Catholic). Some discourses encountered presented the constant comparative question, which seeks to explain the normality of same-sex parent adoption, compared to heterosexual examples, as can be observed: "Every couple that has the financial and psychological ability to take responsibility for a child is able to adopt, being homosexual or heterosexual" (Participant 047, 23 years of age, incomplete higher education, man, bisexual, non-practicing Catholic). What infers acceptance of this is that the parents are people that are well adjusted and financially structured in society.

Social representations were found that shifted the prejudice to society (i.e. being in favor, but thinking it would not be appropriate, because society is prejudiced and believing that bullying would be constantly experienced in the lives of children, creating people with psychological problems). In this sense, this discourse characterized, in part, some representations identified in the sample, "The adoption is the same, I have no prejudice against this, but society in general is very oppressive" (Participant 234, 32 years of age, high school, woman, heterosexual, Evangelical).

The Hierarchical Descending Classification (HDC), which corresponds to the social representations about child development in the same-sex parent context that form corpus 2, was composed of 576 ICUs and 651 ECUs, with an occurrence of 13,175. Corpus 2 was divided into five text segment classes, and aimed to describe the words in which the chi-square values were $X^{2}$ $\geq 15.13$. As can be seen in Figure 2, the dendrogram has three representational fields, one corresponding to classes 1 and 2, the other classes 3 and 4 , and finally the third field formed by class 5. It was noted that the first two representational fields opposed to each other, as the first was composed by classes 1 and 2, which were called respectively "healthy development" and "inadequate development" and the second by classes 3 and 4, entitled "prejudicial society" and "egalitarian adoption". Class 5 included a single text segment called "complete normality". 


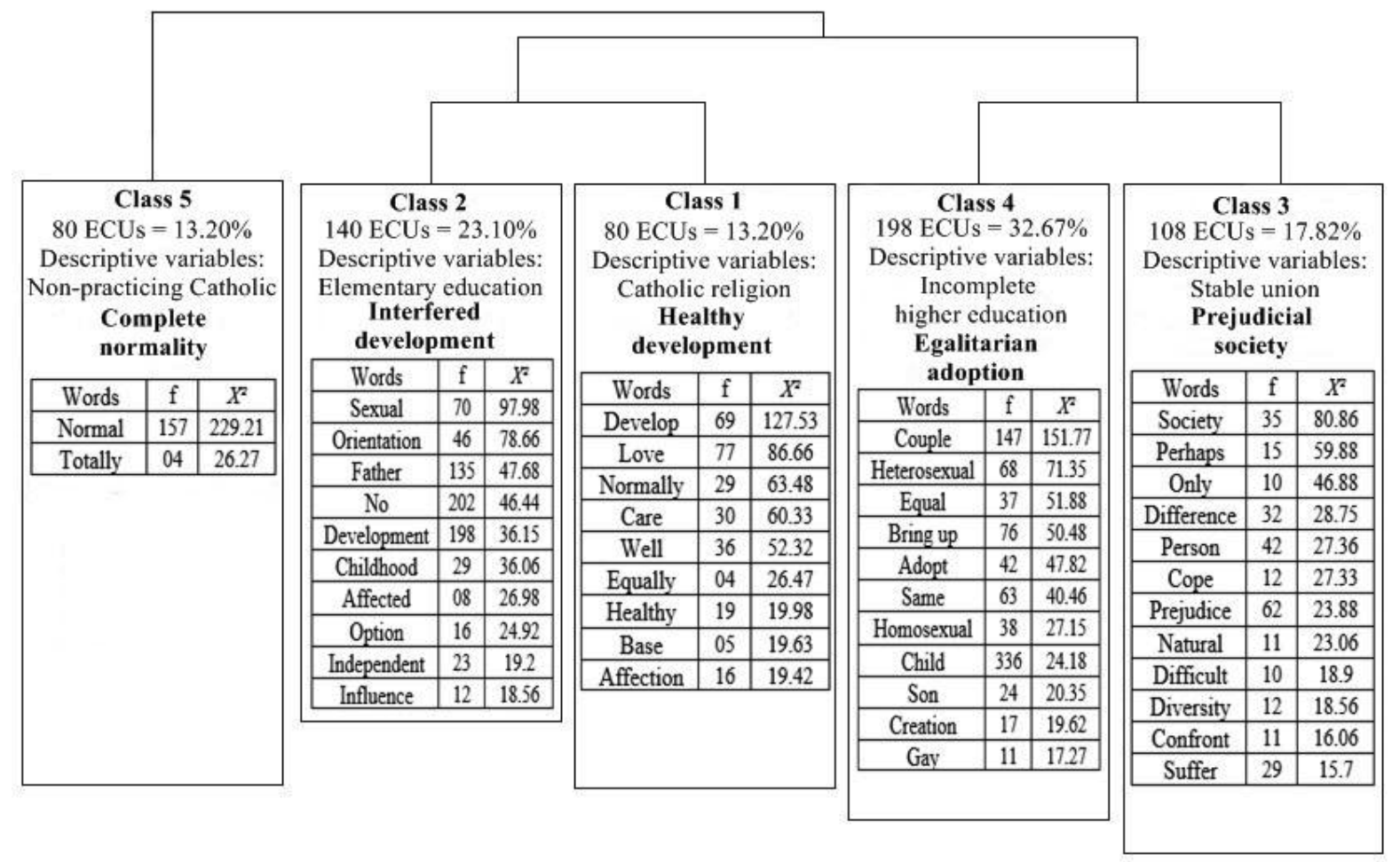

Figure 2. Dendrogram 2, distribution of the classes in the Social Representations of the childhood development in the same-sex parent context.

Class 1 was composed of 140 ECUs, 23.1\% of the total, in which the most relevant descriptive variable was the Catholic religion. In the dendrogram of Figure 2, it can be seen that the words refer to the representations relevant to childhood development, pointing out that the development would be normal, because, as there is a relationship of love and affection, this will tend to be healthy. The following discourse shows the general aspects that composed this class:

The childhood development of a child is healthy if it receives love, attention, warmth, care and affection, whether the parents are heterosexual or not. A homosexual couple will provide good development for a child, regardless of their sexual choice, since what matters for healthy development goes beyond the sexuality of the parents. (Participant 127, 19 years of age, incomplete higher education, bisexual, agnostic)

Class 1 also shows that the development should be the same, considering that a family base is required, regardless of the sexual orientation of the parents. In class 2, with 140 ECUs, $23.1 \%$ of the total, the descriptive variable that stood out was elementary education. This class showed some degree of opposition in relation to class 1, highlighting terms that considered the social representations of the development being possibly influenced by the sexual orientation of the parents, however, it also explored the meaning of being a good choice regardless of the orientation of the parents.

The word "no", as can be seen, was associated with negative words (i.e., not agreeing, seeing a problem with this, not feeling sure, which were mainly present in the discourses of the Brazilian Evangelicals). However, positions can be observed that originate from the no, but demonstrate favorability, that is, representations that anchor their beliefs in "I do not see any problem" or "we should not infer that". This discourse can be observed in the statement of participant 320, 21 years of age, Catholic, with incomplete higher education and heterosexual, who said " $I$ believe that the child will develop normally, I do not believe it would suffer any psychological or physical harm".

In class 3, which included 108 ECUs, referring to $17.82 \%$ of the total, the descriptive 
variable that prevailed was stable union. This class was referred to as the "prejudicial society", which on one hand indicates negative words that show that the child will suffer prejudice and have difficulty with this, however, in another way, constructs a concept related to the difference that can be confronted and coped with, because diversity in society exists (i.e., there is prejudice, but that does not mean that the child will absorb it and grow up burdened with traumas). Participant 316, 19 years of age, who had incomplete higher education, was heterosexual and a nonparticipating Catholic, conversed concisely and basically explained the social representations of this class: "It will be development with some difficulties due to the prejudice of the people, but knowing how to cope with these difficulties, the development will be normal like other children".

Class 4, which included the majority of the ECUs, with a total of 198 , or $32.67 \%$, indicates the sense of egalitarian adoption, noting that heterosexual or homosexual couples will provide the necessary support for growing up. Regarding the descriptive variable most evident, people who were higher education students were those that most demonstrated social representations according to the class. It appears as a way to explain their opinions, with them anchored in a belief in something that knows and gives a similar meaning, arising thus, the social representations, and, in this class, the assignment of an egalitarian factor to the adoption, showing that the people tend to base themselves on the common concept of having a position regarding the new theme that emerges in society.

In this context, the following sentence clearly addresses the type of social representations underlying class 4 (see Figure 2). As can be exemplified in the following statement:

A child of a homosexual couple has the same conditions as a child of heterosexuals. This story that children adopted by homosexual will grow and be influenced by the parents to turn homosexual does not have much foundation, if it were true, children of heterosexual couples would be influenced by their parents to be heterosexual, and thus, homosexuals would have never existed. (Participant 396, 19 years of age, incomplete higher education, genderqueer)

As regards the context of egalitarian adoption, class 5, which had 80 ECUs, $13.2 \%$ of the total, had a more significant descriptive variable, non-practicing Catholics. This class had only two words with enough value to be relevant, showing the childhood development in the same-sex parent context as completely normal.

In the data set of this investigation, it can be observed that there were two textual corpus related to social representations of adoption and childhood development. These results are relevant to the extent that they allow a comprehension of the rights gained by homosexual people, starting from the socially developed concepts that anchor justifications in positive precepts, associated with adoption and childhood development as equal in any context. Thus, it is necessary that adopters make available psychosocial benefits that make the children aware of the qualifications and basic social skills for living in Brazilian society, providing education and autonomy for healthy development.

\section{Discussion}

From the data gathered from the Brazilian adults regarding the social representations of adoption and child development in the samesex parent context, favorable positions were observed. These demonstrate acceptance of the legitimacy of this right, since adoption is a way to promote the happiness of the children and the couples that seek to constitute a family.

It should be mentioned that, despite the new adoption law, No. 12.010/2009, and with part of the population showing support, it is known that there is fear to adopt among homosexual couples, since there are still psychosocial and institutional barriers inherent in society regarding the adoption process by same-sex parent families (Baiocco \& Laghi, 2013).

From studies that investigate social representations, attitudes and opinions, the underlying need can be seen for the provision of legal support for the effective existence of same-sex 
parent adoption in Brazilian society, with these studies reporting the need for recognition that every family needs to follow the childhood and social development of the child (Araújo \& Oliveira, 2008).

People take a certain amount of time to conceive new representations, however, the incidence of debates centered around homosexual people, has contributed to positive representations about same-sex parent adoption. Previously conducted studies have showed that negative positions exceed positive ones (Araújo et al., 2007; Cerqueira-Santos \& Santana, 2015; Pacilli, Taurino, Jost, \& van der Toorn, 2011).

Regarding the differentiation between gay men and lesbians, there is a greater acceptance of couples formed by two women, because there are beliefs related to the supposed maternal instinct of raising children (Costa et al., 2013). Thoughts based on heteronormativity demonstrate rejection that correlates prejudice with homosexual people to prejudice in relation to parenting among same-sex parents (Frias-Navarro, Monterde-i-Bort, Barrientos-Delgado, BadenesRibera, \& Cardenas-Castro, 2014).

Bisexual people, since they are part of the LGBT public, are more likely to accept the act of same-sex parent adoption (Freires, 2015), as are Spiritualists, with the literature documenting that they have spirituality that is open to emerging issues in society (Dias, 2011) . Heterosexuals, in their discourses, address the issues of verifying that the homosexual couple has secure conditions to adopt (Costa et al., 2013), in this sense, this study showed that bisexual and Spiritualist people were those that had the social representations more supportive of same-sex parent adoption, with the heterosexual people having partly supportive social representations.

On the other hand, previous studies have found that negative attitudes are being deconstructed and losing ground to beliefs that contemplate the context of acceptance and that express the desire to reduce social disparities and implement public measures that mark a new moment, that of equality (Baiocco, Argalia, \& Laghi, 2014; Freires, 2015). As highlighted by
Cecilio et al. (2013), the visibility of same-sex parent families as a possible and non-traditional context has forced kinship relations to be thought about from different perspectives.

In this context, anti-prejudicial pressures that are present in society, have a key role in reducing the stigmas and taboos and have, in turn, decreased the manifestations related to flagrant and subtle prejudice (Pereira, Monteiro, \& Camino, 2009). Discrimination due to of gender and sexual orientation still exists, however, the reduction of levels of prejudice through the comprehension of gender issues can lead to more assertive positions.

In summary, the results of this study indicate that homosexual couples should be granted the right to adopt, due to the fact that the majority of the sample demonstrated favorable social representations. From the assumption that responsibility, affection and dedication are what is needed for safe adoption, as is presented in the study results, certainly, these are the resources necessary for adequate psychosocial development that favors the integration of the child into the family and society.

Homosexual families provide society with the possibility of reinventing these parental relationships (Cerqueira-Santos \& Santana, 2015). The constitutional interpretation occurs through public debates and not by stigmatizing concepts reduced to moralism and religious dogmas (Barroso, 2011). The need can be seen for public policies with scope to reduce intolerance, social stigma and prejudice against the establishment of same-sex parent families in the reality of the country.

Even though the Federal Constitution of 1988 addresses the principle of equality, clear and precise legislation regarding homosexual rights would provide a greater possibility of freedom, equality, dignity and safety for the LGBT population (Barroso, 2011; Dias \& Reinheimer, 2013). Thus, not only does the legislation highlight that legal protection should be consolidated, but the scientific production that underpins childhood development in same-sex parent families also shows that this does not 
cause biopsychosocial damage to the child and/ or adolescent (Baiocco et al., 2014; CerqueiraSantos \& Santana, 2015; Freires, 2015; Patterson, 2006). An arduous adoption process hinders the realization of this, however, the persistence of LGBT couples means that there are numerous positively consolidated cases (Machin, 2016).

Institutional changes arise from individual changes and, day after day, the subjects seek to comprehend new issues and begin to reduce the stigma related to homosexual people (Costa et al., 2013). Because of this, Brazil has consolidated some rights and, consequently, goes in search of others, the consummation of which will create a more supportive, inclusive and assertive country regarding sexual diversity and rights.

In this context, it can be noted that the results presented complex representational fields that support the sense of change that society is going through. Underlying this, the empirical data obtained here should designate measures to be considered by institutions to explain the progress of these subjects, coming from common sense and becoming scientific. Through these spheres of social representations, the relevance of the theme, that has been greatly discussed, can be observed throughout this article. Therefore, the relevance is essential to support positions with a view based on scientific research and jurisprudence.

\section{Final Considerations}

This study demonstrated that, even though there is prejudice, there are other ways to view the phenomenon of same-sex parent adoption, with this hegemony of LGBT prejudice losing ground to achievements arising from common mobilization. In this sense, this study served to correlate social representations surrounding the national context, encompassing diverse types of participants, including various types of religion, political positions, levels of education, sexual orientation, ages and other variables that characterize the diversity of Brazilian citizens. Therefore, the contribution of this work for this phenomenon, that instigates innumerable dis- cussions in the country, is important, indicating assertive thoughts that reduce prejudice and negative stereotypes regarding same-sex parent adoption.

The data collection was a social intervention in itself, as it made 589 adults from different Brazilian regions reflect on the subject in question and certainly discuss it with others. The scientific process is fundamental for cooperation in changing the social representations and attitudes of the population, as the practice of the social sciences leads to substantiation of their quotidian concepts (social representations).

Being conducted online, meant that the majority of participants were highly educated, being mostly higher education students, which probably led to acceptance by the majority of the sample. However, studies from the previous decade show unfavorable attitudes even among university students (Araújo \& Oliveira, 2008; Araújo et al., 2007), with studies from the beginning of the current decade recording reductions in the levels of prejudice (Costa et al., 2013; Pereira et al., 2013). Education contributes to positivity, however, the evidence that society is shaping itself goes beyond this sample bias.

Regarding the limitations of this study, there was some difficulty in recruiting the participants, even online, and there were a lot of refusals, demonstrating an obstacle that people have in talking about topics that are deemed "controversial" for society. This may reflect a certain social desirability, which may also have motivated the positivity of the social representations. It was observed that the people accepted the adoption and childhood development, but they justified this saying that society is prejudicial. Another obstacle was the limited number of studies on the subject, especially in the Brazilian context.

Overall, this study can be seen as serving as a resource, in professional training, graduation courses and lectures, to generate new discussions and reflections regarding adoption and childhood development in the same-sex parent context, which can foster and execute public policies that enforce the right to constitute a family 
by same-sex couples. The need for legitimized inclusion in the various social institutions can then be contemplated

It is expected that the results shown here may assist in new constructs on the subject, as, it is from the measurement of constructs that political manifestations can theoretically be stimulated to guide the practice and can insert the social representations of same-sex parent adoption through various dimensions into the institutions, with principles of respect and citizenship. It is suggested that further studies are performed with specific samples, such as people with less access to information, education professionals and others, in different contexts in the world, which could encompass even more divergent thoughts.

\section{References}

Almeida, M. (2008). A adoção por homens que tem sexo com homens: Um caminho para o exercício da parentalidade. In Conselho Federal de Psicologia, Adoção: Um direito de todos e todas (pp. 27-30). Brasília, DF: Author.

Araújo, L. F., \& Oliveira, J. S. C. (2008). A adoção de crianças no contexto da homoparentalidade. Arquivos Brasileiros de Psicologia, 60(3), 40-51.

Araújo, L. F., Oliveira, J. S. C., Sousa, V. C., \& Castanha, A. R. (2007). Adoção de crianças por casais homoafetivos: Um estudo comparativo entre universitários de Direito e de Psicologia. Psicologia \& Sociedade, 19(2), 95-102.

Arruda, Â. (2002). Teoria das representações sociais e teorias de gênero. Cadernos de Pesquisa, 117(127), 127-147.

Baiocco, R., Argalia, M., \& Laghi, F. (2014). The desire to marry and attitudes toward samesex family legalization in a sample of Italian lesbians and gay men. Journal of Family Issues, 35(2), 181-200. doi:https://dx.doi. org/10.1177/0192513X12464872

Baiocco, R., \& Laghi, F. (2013). Sexual orientation and the desires and intentions to become parents. Journal of Family Studies, 19(1), 90-98. doi:https://dx.doi.org/10.5172/jfs.2013.19.1.90

Barroso, L. R. (2011). Diferentes, mas iguais: O reconhecimento jurídico das relações homoafetivas no Brasil. Revista Brasileira de Direito Constitucional, 17(1), 105-138.
Bergman, K., Rubio, R. J., Green, R. J., \& Padròn, E. (2010). Gay man who become fathers via surrogacy: The transition to parenthood. Journal of GLBT Family Studies, 6, 111-141. doi:https:// dx.doi.org/10.1080/15504281003704942

Camargo, B. V., \& Justo, A. M. (2013). IRAMUTEQ: Um software gratuito para análise de dados textuais. Temas em Psicologia, 21, 513518. doi:http://dx.doi.org/10.9788/TP2013.2-16

Cecílio, M. S., Scorsolini-Comin, F., \& Santos, M. A. (2013). Produção científica sobre adoção por casais homossexuais no contexto brasileiro. Estudos de Psicologia (Natal), 18, 507-516. doi:http://dx.doi.org/10.1590/S1413294X2013000300011

Cerqueira-Santos, E., \& Santana, G. (2015). Adoção homoparental e preconceito: Crenças de estudantes de direito e serviço social. Temas em Psicologia, 23(4), 873-885. doi:https://dx.doi. org/10.9788/TP2015.4-06

Costa, P. A., Caldeira, S., Fernandes, I., Rita, C., Pereira, H., \& Leal, I. (2013). Atitudes da população portuguesa em relação à homoparentalidade. Psicologia: Reflexão e Crítica, 26(4), 790-798. doi:http://dx.doi.org/10.1590/S010279722013000400020

Delacruz, A. M. A., \& Uziel, A. P. (2014). Transformações sociais e culturais da família: Considerações iniciais a partir de um caso. Revista Conexões Psi, 2, 57-83.

Dias, J. R. D. L. (2011). Percursos da racionalização do sagrado no espiritismo: Um conjunto de ideias presentes na literatura e na imprensa brasileira (Doctoral dissertation, Pontifícia Universidade Católica do Rio Grande do Sul, Porto Alegre, RS, Brazil).

Dias, M. B., \& Reinheimer, T. L. (2013). Homoparentalidade: Uma realidade. In C. J. Cordeiro \& J. A. Gomes (Eds.), Temas contemporâneos de direito das famílias (pp. 6-503). São Paulo, SP: Pillares.

Fiuza, M. (2015, March 20). Pela primeira vez, STF reconhece direito de adoção por casais homossexuais. Jusbrasil Retrieved from http://moemafiuza.jusbrasil.com.br/noticias/175556906/ pela-primeira-vez-stf-reconhece-direito-de-adocao-por-casais-homossexuais?ref=topic_feed

Freires, L. A. (2015). Atitudes frente a homoparentalidade: Uma explicação a partir de variáveis explícitas e implícitas (Doctoral dissertation, 
Universidade Federal da Paraíba, João Pessoa, PB, Brazil).

Frias-Navarro, D., Monterde-i-Bort, H., BarrientosDelgado, J., Badenes-Ribera, L., \& CardenasCastro, M. (2014). Beliefs about children's adjustment in same-sex families: Spanish and Chilean university students. The Spanish Journal of Psychology, 17, E5. doi:http://dx.doi. org/10.1017/sjp.2014.5

Gato, J., \& Fontaine, A. M. (2010). Desconstruindo preconceitos sobre a homoparentalidade. LES Online, 2(2), 14-21.

Grossi, M. P. (2003). Gênero e parentesco: Famílias gays e lésbicas no Brasil. Cadernos Pagu, 21, 261-280.

Instituto Brasileiro de Geografia e Estatística. (2011). Censo Demográfico 2010. Rio de Janeiro, RJ: Author.

Jodelet, D. (2001). As representações sociais. Rio de Janeiro, RJ: Editora da Universidade do Estado do Rio de Janeiro.

Law No. 12.010. (2009, September 02). Diário Oficial da União. Retrieved from http://www.planalto.gov.br/ccivil_03/_ato2007-2010/2009/lei/ 112010.htm

Law No. 8.069. (2014). Statute of Children and Adolescents. Retrieved from http://www.conselhodacrianca.al.gov.br/sala-de-imprensa/publicacoes/ECA\%20ATUALIZADO.pdf/view

Machin, R. (2016). Homoparentalidade e adoção: (RE) Afirmando o seu lugar como família. Psicologia \& Sociedade, 28(2), 350-359. doi:https:// dx.doi.org/10.1590/1807-03102016v28n2p350

Moscovici, S. (2003). Representações Sociais: Investigações em Psicologia Social. Petrópolis, RJ: Vozes.

Murphy, D. A. (2013). The desire for parenthood: Gay men choosing to become parents through surrogacy. Journal of Family Issues, 34, 1104-1124. doi:http://dx.doi. org/10.1177/0192513X13484272

Nascimento, A. R. A., \& Menandro, P. R. M. (2006). Análise lexical e análise de conteúdo: Uma proposta de utilização conjugada. Estudos e Pesquisas em Psicologia, 6(2), 1-17.

National Council of Justice. (2015). Processos relacionados à adoção no Brasil: Uma análise sobre os impactos da atuação do Poder Judiciário. Brasília, DF: Author.
Pacilli, M. G., Taurino, A., Jost, J. T., \& van der Toorn, J. (2011). System justification, right-wing conservatism, and internalized homophobia: Gay and lesbian attitudes toward same-sex parenting in Italy. Sex Roles, 65(7-8), 580-595. doi:http:// dx.doi.org/10.1007/s11199-011-9969-5

Passos, M. C. (2005). Homoparentalidade: Uma entre outras formas de ser família. Psicologia Clínica, 17(2), 31-40.

Patterson, C. J. (2006). Children of lesbian and gay parents. Current Directions in Psychological Science, 15(5), 241-244.

Pereira, A., Monteiro, M. B., \& Camino, L. (2009). Social norms and prejudice against homosexuals. The Spanish Journal of Psychology, 12, 576-584. doi:http://dx.doi.org/10.1017/ S1138741600001943

Pereira, C. R., Torres, A. R. R., Falcão, L., \& Pereira, A. S. (2013). O papel de representações sociais sobre a natureza da homossexualidade na oposição ao casamento civil e à adoção por famílias homoafetivas. Psicologia: Teoria e Pesquisa, 29(1), 79-89. doi:http://dx.doi. org/10.1590/S0102-37722013000100010

R Development Core Team. (2011). R: A language and environment for statistical computing. Vienna, Austria: R Foundation for Statistical Computing.

Ratinaud, P. (2009). IRAMUTEQ: Interface de R pour les Analyses Multidimensionnelles de Textes et de Questionnaires [Computer software]. Retrieved from http://www.iramuteq.org

Ratinaud, P., \& Marchand, P. (2012). Application de la méthode ALCESTE à de" gros" corpus et stabilité des" mondes lexicaux": analyse du" Cable-Gate" avec IraMuTeQ. Actes des 11eme Journées Internationales d'Analyse Statistique des Données Textuelles, 835-844.

Reinert, M. (1990). Alceste: une methologie d'analyse dês donnees textualles et une application. Bulletin de Méthodologie Sociologique (Paris), 28, 24-54.

Resolution No. 175, of May 14, 2013. (2013). Enunciado Administrativo $N^{o} 14$, de 14 de maio de 2013. Brasília, DF: National Council of Justice. Retrieved from http://www.cnj.jus.br/images/ imprensa/resolu\%C3\%A7\%C3\%A3o_n_175. pdf

Silva, D. A., \& Uziel, A. P. (2011). Esta é uma casa de família! A homoparentalidade sob o olhar 
de duas diferentes gerações. In Anais II Seminário Internacional Enlaçando Sexualidades. Salvador, BA: Universidade do Estado da Bahia. Retrieved from https://nugsexdiadorim. files.wordpress.com/2011/12/esta-c3a9-umacasa-de-famc3adlia-a-homoparentalidade-sobo-olhar-de-duas-diferentes-gerac3a7c3b5es.pdf

Silva, M. P., \& Silveira, F. C. (2015). Adoção Homoafetiva à luz do princípio da dignidade da pessoa humana. Judicare, 7(1), 32-49. Retrieved from http://ienomat.com.br/revistas/index.php/ judicare/article/view/130

Uziel, A. P. (2007). Homossexualidade e adoção. Rio de Janeiro, RJ: Garamond.
Xavier, P., Mendes, F., Martins, E., \& Fernandes, R. (2011). A homoparentalidade na perspectiva de estudantes do Ensino Superior. In Actas do XI Congreso Internacional Galego-Portugués de Psicopedagoxía. Revista Galego-Portuguesa de Psicoloxía e Educación.

Zambrano, E. (2006). Parentalidades “impensáveis": Pais/mães homossexuais, travestis e transexuais. Horizontes Antropológicos, 12, 123-147.

Recebido: $27 / 02 / 2016$

$1^{a}$ revisão: 19/11/2016

$2^{a}$ revisão: 07/02/2017

Aceite final: 14/02/2017

(C) The Author(s), 2018. Open Access. This article is distributed under the terms of the Creative Commons Attribution 4.0 International License (http://creativecommons.org/licenses/by/4.0/), which permits unrestricted use, distribution, and reproduction in any medium, provided you give appropriate credit to the original author(s) and the source, provide a link to the Creative Commons license, and indicate if changes were made. 